Article

\title{
Attribution Analyses of Impacts of Environmental Changes on Streamflow and Sediment Load in a Mountainous Basin, Vietnam
}

\author{
Jie Wang ${ }^{1, *}$, Ishidaira Hiroshi ${ }^{2}$, Shaowei Ning ${ }^{3}$, Timur Khujanazarov ${ }^{4}$, Guiping Yin ${ }^{5}$ and \\ Lijuan Guo ${ }^{5}$ \\ 1 College of Hydrometeorology, Nanjing University of Information Science \& Technology, \\ Nanjing 210044, China \\ 2 International Research Center for River Basin Environment, University of Yamanashi, Kofu, \\ Yamanashi 4008511, Japan; ishi@yamanashi.ac.jp \\ 3 School of Civil Engineering, Hefei University of Technology, Hefei 230009, China; yantaigold@sina.com \\ 4 Water Resources Research Center, Disaster Prevention Research Institute, Kyoto University, \\ Uji, Kyoto 6110011, Japan; exider@gmail.com \\ $5 \quad$ Nanjing Water Planning and Designing Institute Co., Ltd, Nanjing 210006, China; yingp008@126.com (G.Y.); \\ 365843295@163.com (L.G.) \\ * Correspondence: wangjie0775@163.com; Tel.: +86-25-5869-5622
}

Academic Editors: James M. Vose and Ge Sun

Received: 29 November 2015; Accepted: 21 January 2016; Published: 29 January 2016

\begin{abstract}
Located in the southeastern China and northern Vietnam, the Red River is an important international trans-boundary river that has experienced rapid deforestation and environmental changes over the past decades. We conducted attribution analysis of impacts of various environmental changes on streamflow and sediment load. The contribution of reclassified environmental changes to total change of the streamflow and sediment load was separated. Land cover change based on climate-induced and human-induced indicators were defined. We found that human-induced land cover change was the main factor affecting changes of the streamflow and sediment load. Changes of the land cover were more pronounced in the dry season than in the wet season whereas sediment load changed more in the wet season than in the dry season. In addition, changes in sediment load were mainly caused by human-induced land cover change and the changes of land cover were more influential on sediment load than on streamflow in the Red River basin.
\end{abstract}

Keywords: human activities; climate change; land cover change; separation; streamflow; sediment load

\section{Introduction}

Understanding hydrological responses to catchment environmental changes is important in watershed management worldwide [1,2]. The hydrological cycles of river basins depend on climatic regime, land cover, geology, topography and other human activities. However, climate change has been the main concern recently. Climate change has resulted in rise of the atmospheric temperature and modified precipitation patterns, which has directly led to alteration in runoff [3] and thus sediment load in the river flow [4]. Another important factor altering hydrological cycles is land cover change, such as deforestation, farming activities, climate-induced and human-induced land cover change. Such land cover changes are directly linked to changes to the ecosystem structure (e.g., leaf area index) altering the evapotranspiration rates and flow velocity [5] and physical structure such as surface roughness that can also modify soil erodibility and consequently impact the sediment load in river basins [6]. River discharge and sediment load are affected by various environmental changes within a 
drainage basin in an integrated way [7,8].In addition, human activities such as dam construction and agricultural irrigation, had seriously changed hydrological cycle in most river basins.

Streamflow or sediment load characteristics of a watershed are closely related to the geology, topography, climate, land cover and human activities within the basin. While geologic and topographic variables are fixed in the short term, long-term changes occur in climatic conditions. On the other hand, human activities or land cover changes would produce abrupt alterations in streamflow, erosion process and sediment load [7]. All environmental changes play an important role in altering surface flow and sediment yield. Sun et al. [2] argued that climate change was more crucial to the hydrological cycle changes in four Poyang Lake basins than vegetation. Wang and Ishidaira [4] suggested that the total changes of runoff or sediment load in Red River basin was caused by climate variation and human activities, mainly on land cover change. Nguyen Ngoc and Lung [9] concluded that if the forest cover of the catchment is reduced from $70 \%-80 \%$ to $40 \%-50 \%$, soil erosion will increase by $27.1 \%$ and surface flows will increase by $33.8 \%$. Land cover change was demonstrated as a crucial factor of changes in water yield, sediment load and nonpoint water pollution [6-8].

Quantitative contribution of all these impacts on changes in the streamflow and sediment load has been thoroughly investigated $[4,8,10]$. However, little quantitative knowledge is available on individual impacts of the various environmental changes on streamflow and sediment load. There are two main ways to study separating effects of the climate and the land cover change. One traditional way is a paired catchments experiment [10]. Although this approach is the "good standard" in quantifying the impacts of land cover changes, it is quite costly and time-consuming. Another approach is a simulation method. Model simulation methods account for streamflow or sediment load change response to climate variability and land cover change or human activities $[4,8]$, with the assumption that the total changes of runoff or sediment load is caused by climate variation and human activities or land cover change. For instance, Zhao et al. [11] calculated different contributions of human activities and climate change on streamflow change in the upper catchment of the Yellow River Basin using the Geomorphology Based Hydrological Model (GBHM) and sensitivity-based method. Tang et al. [8] evaluated separated effects of variations in land cover and climate on runoff and water quality in the upper catchment of the Miyun Reservoir in northern China using the GBHM hydrological model. Wang and Ishidaira [4] applied the Soil and Water Assessment Tool (SWAT) model to separate impacts of climate change and human activities on the streamflow and sediment flow in the Red River basin and concluded that land cover change is the main human activity to alter the streamflow and sediment flow in this basin. Most of these studies assumed that land cover changes were caused by human activities without separating the climate-induced land cover change from human-induced land cover change and other human activities, and climate change only included meteorological changes (such as precipitation, temperature changes). Climate-induced land cover change has been rarely considered as part of climate change in assessing impacts of the climate change on water resources.

To distinguish climate/human-induced land cover change and evaluate the effects of land cover change on the streamflow and sediment load, dynamics of land cover change should be investigated first. While long-term time series of land cover change is not readily available, the Normalized Difference Vegetation Index (NDVI) and Leaf Area Index (LAI) are two of the most widely used vegetation indices to reflect dynamics of land cover degradation caused by human activities and climate changes $[12,13]$. However, NDVI or LAI obtained from remote sensing data can only explain the current vegetation cover with dual influence of climate change and human activities. To investigate potential vegetation cover (e.g., potential LAI) under climate change scenarios excluding human activities, ecosystem simulation models are required. Ecosystem models have additional advantage to considering effects of not only climatic conditions but also other factors such as carbon dioxide concentrations.

The objective of this study is to design framework to quantitatively assess the impacts of various environment changes on the streamflow and sediment load in the Da River Basin. We used a hydrological model and new sediment rating curve to conduct multiple scenario analysis to separate 
the individual effects of environment changes on streamflow and sediment load. Specifically, our main focuses are: (1) to determine the period with the most drastic artificial disturbance; (2) to determine LAI time series from Glaobal Inventory Modelling and Mapping Studies (GIMMS) to analyze changing trends of the actual land/vegetation cover in the past years, and to model potential LAI by an ecosystem model to describe the potential land/vegetation cover condition without human activities; (3) to evaluate hydrological models and new sediment rating curves; (4) and to separate environment change effects on streamflow and sediment load.

\section{Study Area and Data Description}

\subsection{Study Area}

The Da River, originated from Yunnan Province, China, is one of the largest tributaries of the Red River representing a trans-boundary river shared between Vietnam and China (Figure 1). The catchment area of the Da River is approximately $55,000 \mathrm{~km}^{2}$. Mountainous landscapes dominate in the Da River Basin (DRB), with narrow and steep slopes. Mean elevation is at $1836 \mathrm{~m}$, but maximal elevation reaches $3318 \mathrm{~m}$ and the minimal one is of $5 \mathrm{~m}$ (Figure 1). The geologic substratum of the upper basin is dominated by consolidated paleozoic sedimentary rocks of complex lithology, with variable contributions of mesozoic silicic or carbonate rocks [3]. Soils in the upper basin are typically Ultisols and alluvial soils with little variation spatially [14]. Mountain areas in the upstream are tectonically active and unstable, and this, combined with intense rainfall, causes high erosion [15].

Climate is dominated by tropical monsoon with annual mean rainfall about $1320 \mathrm{~mm}$, in two seasons with the wet season (May to October) receiving $85 \%$ of total precipitation $[3,8]$. The annual mean runoff is about $1168 \mathrm{~m}^{3} / \mathrm{s}$ from 1988 to 2004 at the Lai Chau Station and a total annual sediment load about is $40.1 \times 10^{6}$ ton. The annual mean runoff is about $1660 \mathrm{~m}^{3} / \mathrm{s}$ at Hoa Binh station, which accounts for about half of the maximum discharge in the Red River basin.

The overall sediment load of the Red River ranks ninth in the world. Sediment yield of the river is important to investigate as the Vietnamese government has decided to build a cascade of five dams and hydropower facilities in the DRB (Figure 1), for flood control, irrigation and hydropower generation. Up to now, two dams, Son La and Hoa Binh have been completely finished. The Son La reservoir in the DRB with effective storage of $16.2 \mathrm{~km}^{3}$ [3,4] has just been completed in October 2012, becoming the largest dam in Vietnam (Figure 1). The Hoa Binh dam $\left(\mathrm{V}=9.5 \mathrm{~km}^{3}\right)$ located downstream of the Son La dam, was completely finished in 1993 [3].

Deforestation has been a growing concern in the region and upstream of DRB in particular. The region was originally dominated by forest: $70 \%$ of the total DRB was covered by evergreen broadleaf forests with remaining area as croplands and shrublands. The forest coverage of the Chinese part of the river has declined by half [16] from 1950 to 1990 and most rapidly in 1993 [17]. Vietnamese forest cover decline has been even more rapid over the same time period replacing or felling more than $70 \%$ of previously forest area especially in upstream mountainous regions [18]. Since 1995, several forest rehabilitation programs have been established and overall forest area of Vietnam has continuously increased; however, the Da River Basin still has limited forest plantations due to poor accessibility [19]. Compared with original natural forests, young man-made forests have lower canopy density, shallower rooting depth and had limited soil erosion function. Over the last 500 years, deforestation had raised the soil erosion rate by 15 -fold resulting in increased sediment load in the DRB [3]. In addition, according to the observed meteorological data, both rainfall and air temperature show an ascending trend with the average slope of $0.863 \mathrm{~mm} /$ year and $0.014{ }^{\circ} \mathrm{C} /$ year in the past 50 years. Thus, deforestation and climate change have been main factors in intensified soil erosion in the basin.

The Da River has received increasing attention [20] for many eco-hydrological issues, such as flooding, sediment changes and biodiversity losses. Land cover change has caused a great impact on the streamflow and sediment yield process in the Red River basin [4]. For the streamflow of this 
river, Tuan [21] concluded that the peak discharge and the total runoff volume increased as the forest cover area decreased because of the Hoa Binh Reservoir constructions. Ye et al. applied Mann-Kendall and cluster technique methods to analyze the variability of the 45-year runoff series at the Manhao station in the Red River and showed an inverse trend between annual runoff and NDVI [17]. As for the sediment load, Ren et al. [22] analyzed annual sediment load of different periods in Yuan Jiang in the Red River Basin, and showed that annual sediment load in the 1980s was less than in the 1990s, and forest cover had a reverse relationship with sediment load. Dang et al. [23] detected a significant decrease of sediment load after 1990 in the downstream of reservoir, which indicated that the Hoa Binh dam reduced its annual sediment by half. Wang et al. [4] concluded that human activities such as dams or land use changes are the main causes affecting the changes of sediment flow in Red River Basin. However, it is not clear how much each environment change factor affected streamflow and sediment load in the Red River basin.

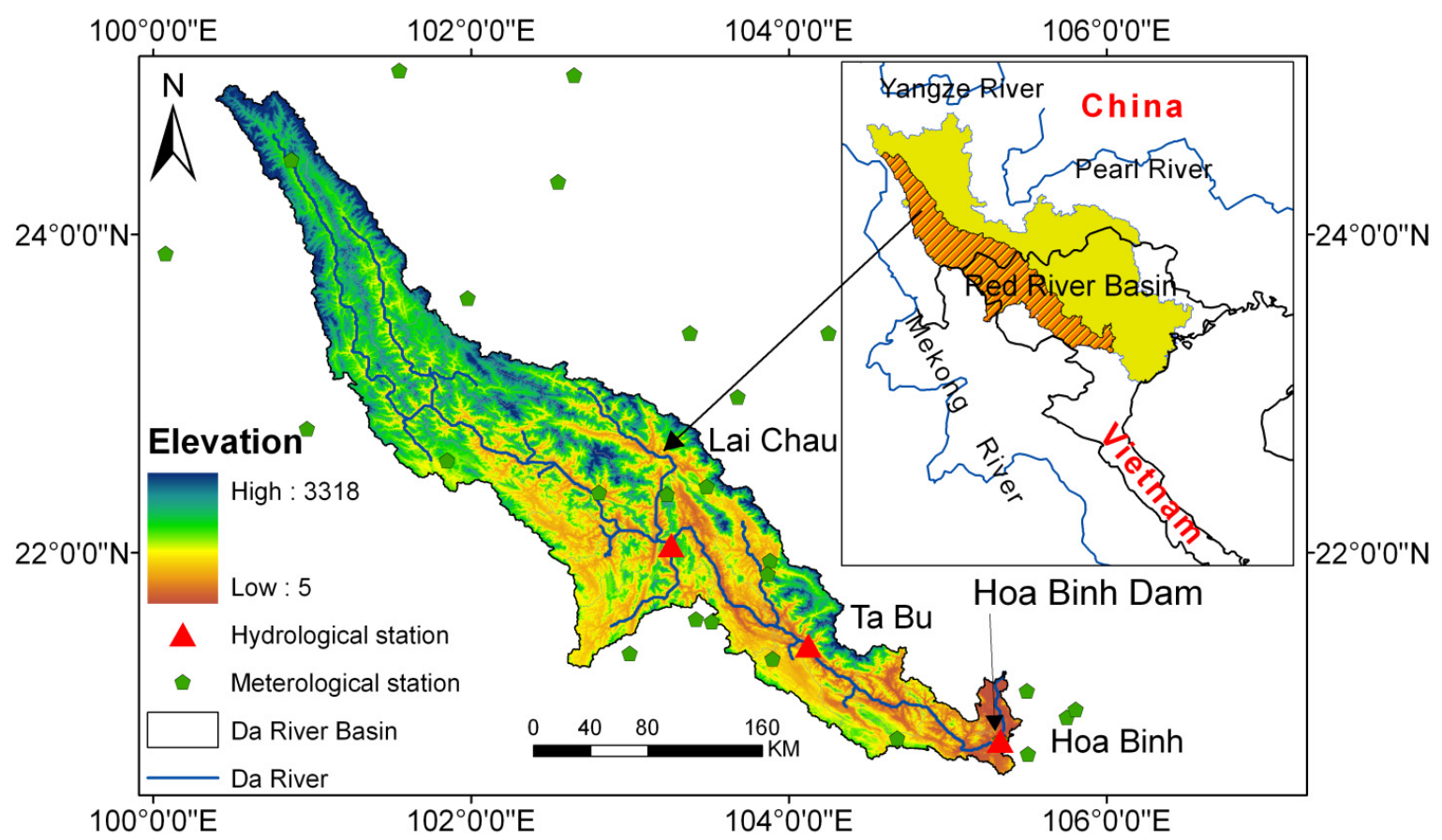

Figure 1. Location of the DRB and the meteorological stations.

\subsection{Dataset}

The hydrological and meteorological datasets covering 1960-2008 were provided by the Vietnam Academy of Science and Technology and the China Meteorological Data Sharing Service Center and are used as inputs for hydrological simulation and sediment load calculations. Daily streamflow data collected from the Lai Chau (LC) and the Ta Bu (TB) stations in the DRB (Figure 1) were used in calibrating and validating the hydrological model. Monthly suspended sediment concentration (SSC) data are also available at the Lai Chau station. Daily meteorological data including precipitation, wind speed, relative humidity, hours of sunshine as well as maximum, minimum, and mean air temperatures were well distributed in the study area, reflecting the climatic characteristics of DRB.

We also used 0.25 degree gridded daily precipitation and average temperature data from APHRODITE's Water Resources Project [24]. In addition, 0.5 degree gridded monthly average daily maximum and minimum temperature data from Climatic Research Unit [25] was introduced to calculate the diurnal temperature range (DTR), which was applied to transform daily average temperature from APHRODITE into daily maximum and minimum temperature. As for other geographical information, elevation data with $1 \mathrm{~km}$ resolution was provided by Global 30 Arc-Second Elevation (GTOPO30) from the U.S. Geological Survey [26,27]. Global Digitized Soil Map and 
effective Soil Depth of FAO-UNESCO with a spatial resolution of $1 \mathrm{~km}$ were used to obtain the soil properties [28]. Global $1 \mathrm{~km}$ Land Cover data obtained from the USGS National Center for Earth Resources Observation Science was employed (http://edcdaac.usgs.gov/glcc/ea_int.html), and the land cover was reclassified into the following seven types: evergreen needle-leaf forest, evergreen broadleaf forest, deciduous broadleaf forest, deciduous needle-leaf forest, evergreen shrubs, C3 and C4 (photosynthesis type) grassland in the study. In addition, annual mean global Carbon Dioxide $\left(\mathrm{CO}_{2}\right)$ data from Ed Dlugokencky and Pieter Tans, Earth System Research Laboratory, National Oceanic \& Atmospheric Administration (NOAA/ESRL) (www.esrl.noaa.gov/gmd/ccgg/trends/) was also used in the ecological model. Global Data Sets of Vegetation Leaf Area Index (LAI 3 g) including a 30 year period from 1982 to 2011 [29] was used to analyze the land cover and develop the new sediment rating curve in our study area. All the geographic data were re-gridded into the same spatial resolution of 0.25 degree to feed with the Biome-Bio Geochemical Cycle (Biome-BGC) ecological model.

\section{Methodology}

\subsection{Determination of Period with Human Distubances}

In order to evaluate environment change effects on streamflow and sediment load, the period of most drastic artificial disturbance should be first determined. The Pettitt mutation approach, widely-used to detect the time of the change in time series [30], was employed to detect the time with an abrupt change in annual streamflow in this study. When this break point was determined, the research period could be divided into two parts: the pre-change period before this year represented as the baseline period without strong human activities and post-change period after the abrupt year was recognized as the most serious period of human activities effect compared with the pre-change period (Figure 2). In addition, time series of NDVI and precipitation was also analyzed to confirm this period. In this study, we only focus on the post-change period associating with significant human activities.

\subsection{Analysis Method}

The total change of streamflow or sediment load should be caused by climate change and human activities in one period. Climate changes include climate-induced land cover change and meteorological change, and human activities include human-induced land cover change and others.

$$
\begin{gathered}
\Delta Q^{\text {tot }}=\Delta Q^{c l i}+\Delta Q^{\text {hum }}, \\
\Delta Q^{\text {hum }}=\Delta Q^{\text {hum-lcc }}+\Delta Q^{\circ \text { thers }}, \\
\Delta Q^{c l i}=\Delta Q^{c l i-l c c}+\Delta Q^{m e t},
\end{gathered}
$$

where $\Delta Q^{\text {tot }}, \Delta Q^{c l i}, \Delta Q^{\text {hum }}, \Delta Q^{\text {hum-lcc }}, \Delta Q^{c l i-l c c}, \Delta Q^{\text {met }}$ and $\Delta Q^{\circ}$ thres represent the change of streamflow caused by all environment changes, climate variability, human activities, human-induced land cover change, climate-induced land cover change, meteorological change and other artificial disturbances, respectively. Calculation of sediment load changes follows the same rule with streamflow.

According to Figure 2, effects of different environmental changes on the streamflow and sediment load were estimated as the following:

$$
\begin{gathered}
\Delta Q^{t o t}=\bar{Q}_{2}^{o b s}-\bar{Q}_{1}^{o b s}, \\
\Delta Q^{h u m}=\bar{Q}_{2}^{o b s}-\bar{Q}_{2}^{s i m_{c l i},} \\
\Delta S L^{t o t}=\overline{S L}_{2}^{o b s}-\overline{S L}_{1}^{o b s}, \\
\Delta S L^{h u m}=\overline{S L}_{2}^{o b s}-\overline{S L}_{2}^{s i m_{c l i}},
\end{gathered}
$$


in which $\Delta Q^{\text {hum }}$ and $\Delta S L^{\text {hum }}$ are the change of streamflow and sediment load due to human activities; $\bar{Q}_{1}^{o b s}, \bar{Q}_{2}^{o b s}, \overline{S L}_{1}^{o b s}$, and $\overline{S L}_{2}^{o b s}$ is the observed streamflow or sediment load in the first or second period, respectively; and $\bar{Q}_{2}^{s i m_{c l i}}$ and $\overline{S L}_{2}^{s i m_{c l i}}$ are the simulated potential streamflow and sediment load only considering climate change effect in the second period.
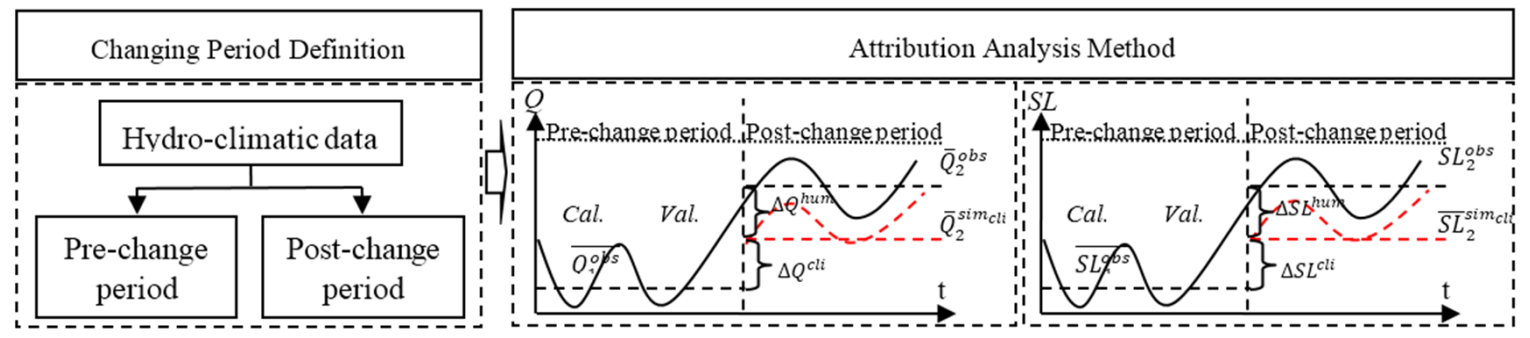

Figure 2. Different period separation and schematic diagram of $\Delta \mathrm{Q}, \Delta \mathrm{SL}$.

Three models are used to evaluate environment changes and their impacts on streamflow and sediment load in DRB: the Biome-BGC Model, the Block wise use of Topography hydrological model with Muskingum-Cunge routing model (BTOPMC) and the New Sediment Rating Curve (NSRC). The models are coupled in a "one-way" manner (Figure 3) and datasets used in these models are summarized in Table 1. A feedback loop is not included, as spatial changes in land cover and temporal dynamic change in LAI are reflected in the basin scale streamflow and sediment load simulation. Biome-BGC is first used to simulate the potential LAI under climate change effect, and BTOPMC and NSRC are validated in the pre-change period in DRB. After this, the potential LAI and actual meteorological data in the post-change period are then inputted into the validated BTOPMC to calculate $\bar{Q}_{2}^{s i m_{c l i}}$. Then, potential LAI and $\bar{Q}_{2}^{s i m_{c l i}}$ are used to drive validated NSRC to get $\overline{S L}_{2}^{s i m_{c l i}}$. Finally, the effect of human activities on streamflow and sediment load can be calculated by the differences between simulated and observed value in the post-change period and the effect of climate variability is the remaining part of the total change.

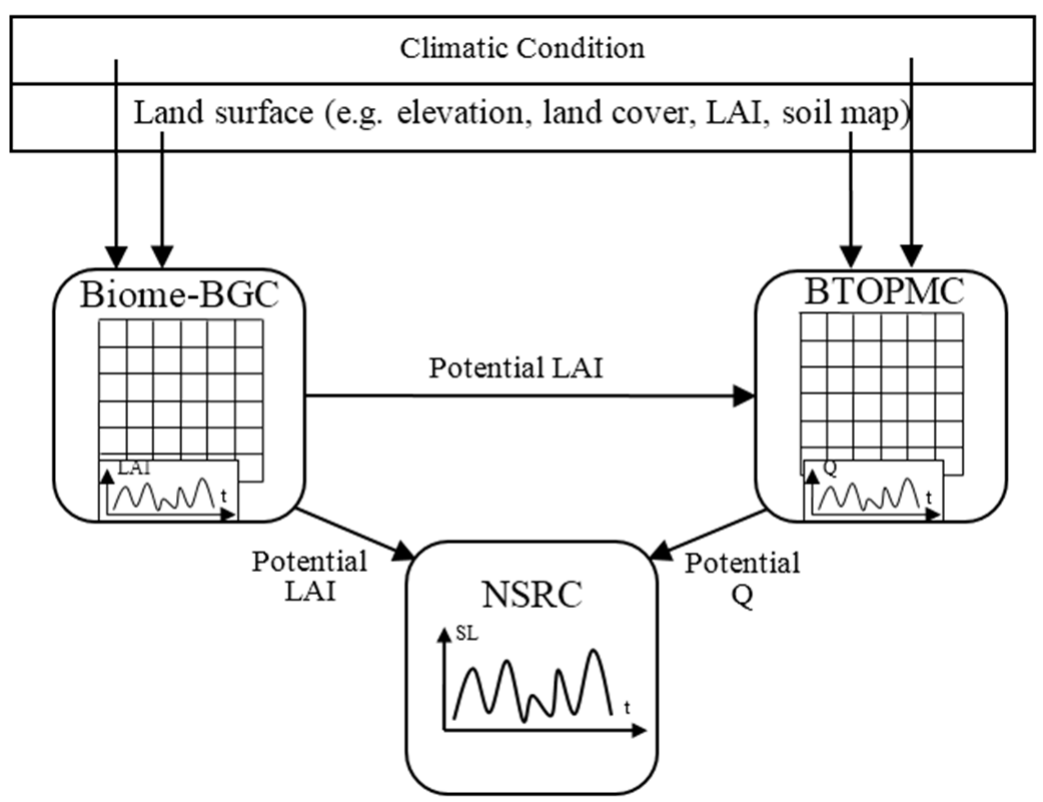

LAI: leaf area index; Q: Streamflow

Figure 3. Model integration and data flow within models. 
Table 1. A summary of input datasets for parameterizing different models.

\begin{tabular}{ccccc}
\hline Data & Temporal Scale & Time Span & Spatial Scale & Data Source \\
\hline Sreamflow & Monthly & $1988-2004$ & Point & Lai Chau station \\
Sediment flow & Monthly & $1988-2004$ & Point & Lai Chau station \\
CO $_{2}$ & Annual & $1959-2014$ & Point & NOAA/ESRL \\
LAI/NDVI & Monthly & $1982-2006$ & Grid $(8 \mathrm{~km})$ & AVHRR-GIMMS(LAI3g) \\
Precipitation & Daily & $1951-2007$ & Grid $\left(0.25^{\circ}\right)$ & APHRODITE's Water Resources Project \\
Average Temp & Daily & $1951-2007$ & Grid $\left(0.25^{\circ}\right)$ & Same as above \\
Max \& Min Temp & Monthly & $1901-2009$ & Grid $\left(0.5^{\circ}\right)$ & Climatic Research Unit \\
DEM & & & Grid $(1 \mathrm{~km})$ & GTOPO30 (USGS) \\
Soil & & 2000 & Grid $(1 \mathrm{~km})$ & FAO-UNESCO \\
Land Cover & & 1992 & Grid $(1 \mathrm{~km})$ & USGS \\
\hline
\end{tabular}

\subsubsection{Hydrological Model}

The BTOPMC is a blockwise grid-based distributed hydrological model developed by the University of Yamanashi, Japan [30,31]. The model extends TOPMODEL concept [32] by adopting the Muskingum-Cunge method for flow routing component on a grid basis and sub-catchments served as blocks [30,31]. This concept helps to address TOPMODEL's limitation in flow timing and heterogeneity for modeling large river basins in the warm humid regions [31,33]. For each grid, four vertical zones are considered for hydrological calculation: vegetation zone, root zone, unsaturated zone and saturated zone [30,31]. The model has been validated on several river basins with various resolutions using remote sensing data and global datasets on ungauged catchments with good performance [30-33]. A more detailed description of the BTOPMC model and its underlying conceptualizations and parameters is found in one reference [30].

In this paper, BTOPMC is applied to simulate streamflow controlled by environment changes such as climate change scenario and LAI change. The maximum soil water capacity of the root zone, the LAI for calculation of actual evapotranspiration, and canopy interception were key parameters to evaluate land cover change effects on the streamflow. Three statistics are applied to assess the performance of BTOPMC model [34]:

(i) Nash-Sutcliffe efficiency (NSE): NSE ranges between $-\infty$ and 1.0 (1 inclusive), with NSE = 1 being the optimal value. Values between 0.0 and 1.0 are generally viewed as acceptable levels of performance;

$$
N S E=1-\frac{\sum_{i=1}^{n}\left(Q_{o b s}-Q s i m_{i}\right)^{2}}{\sum_{i=1}^{n}\left(Q_{o b s}-\overline{Q o b s}\right)^{2}}
$$

(ii) The ratio of root mean squared error to observations standard deviation (RSR): RSR varies from the optimal value of 0 , which indicates perfect performance in simulation, to a large positive value. The lower the RSR, the better the model simulation performance:

$$
R S R=\frac{\text { RMSE }}{S T D E V_{\mathrm{obs}}}=\frac{\sqrt{\sum_{i=1}^{n}\left(\mathrm{Qobs}_{i}-Q \operatorname{Qsim}_{i}\right)^{2}}}{\sqrt{\sum_{i=1}^{n}\left(\mathrm{Qobs}_{i}-\overline{\mathrm{Qobs}}\right)^{2}}}
$$

(iii) Percent bias (PBIAS): PBIAS value should be close to zero. Positive values indicate the model underestimation bias and vice versa;

$$
\text { PBIAS }=\frac{M A E}{\overline{Q o b s}}=\frac{|\overline{Q s i m}-\overline{Q o b s}|}{\overline{Q o b s}} * 100 \%,
$$

where Qsim is simulated value, Qobs is observed value, $\overline{Q s i m}$ is average simulated value, $\overline{Q o b s}$ is average observed value, and MAE is mean absolute error.

When the RSR is less than 0.7 and the NSE is greater than 0.5, the model performance for both streamflow and sediment load calculation is considered as being good [34]. However, values of PBIAS 
for streamflow and sediment load vary significantly [34]. Moriasi [34] defines PBIAS being less than $25 \%$ of a satisfactory indication for the streamflow simulation and PBIAS results less than $55 \%$ are considered acceptable for the sediment load.

\subsubsection{Ecological Model}

Biome-BGC is a biogeochemical point-scale simulation model [35] to estimate the storage and fluxes of carbon, nitrogen and water within terrestrial ecosystems. The model simulates the potential LAI under present climate conditions without human activities, considering changes of both climatic conditions and carbon dioxide concentrations. The model requirement includes daily climate data, $\mathrm{CO}_{2}$, information of the general environment (i.e., soil, vegetation type and site conditions) and parameters describing the eco-physiological characteristics of vegetation. The missing daily meteorological data, which is not available from APHRODITE or Climate Research Unit (CRU) dataset, are estimated by the Mountain Microclimate Simulation Model (MTCLIM) [36]. The Biome-BGC needs "spin-up" simulations to achieve equilibrium conditions when the initial soil and plant compartment pools match the mass balance equations [35]. Biome-BGC emphasizes leaf area index (LAI) as a key structural output, which is calculated by multiplying carbon allocated to leaves times the specific leaf area. Ichii et al. [37] applied this model to simulate the carbon fluxes and gross primary productivity in Amazonian, African and Asian areas. As a result, we also used the model to simulate potential LAI since our study basin is one part of the Asian area. In order to obtain LAI values for all grids, instead of previous point simulation vision for DRB, we developed the grid-based Biome-BGC model with the spatial resolution of 0.25 degree.

\subsubsection{New Sediment Rating Curve}

The calculation of sediment load requires both streamflow and sediment concentration data in river basins. Sediment concentration data are rare since data collection requires manual individual sampling taken at fixed temporal intervals. This type of data is still absent at most hydrological stations especially in developing countries. Physically-based models or sediment rating curves have been used to estimate suspended sediment concentration (SSC). However, physically-based models universally used to simulate SSC tend to suffer from problems associated with the difficulty of huge dataset and the identifiability of parameter values. Conversely, traditional sediment rating curve [38] generally represents a simple power functional relationship relating SSC to streamflow that unfortunately, does not consider temporal dynamic changes of vegetation cover. Vegetation cover, as was discussed above, should have important effects on soil erosion and sediment transport capacity by slowing flow through friction losses [39]. Hence, low intensity vegetation cover condition should provide more sediment flux for the same streamflow. The New Sediment Rating Curve (NSRC) considers vegetation cover (NDVI or LAI) and gives better agreement in sediment simulation result in several Asian basins [40]. The sediment load (SL) is calculated by:

$$
\begin{gathered}
S S C=a\left(1-M_{L A I}{ }^{c}\right) Q^{b} \\
M_{L A I}=\left(L A I-L A I_{\min }\right) /\left(L A I_{\max }-L A I_{\min }\right)
\end{gathered}
$$

in which $a, b$ and $c$ are model parameters for a particular stream; $Q\left(\mathrm{~m}^{3} / \mathrm{s}\right)$ is streamflow; SSC $\left(\mathrm{g} / \mathrm{m}^{3}\right)$ is suspended sediment concentration; $M_{L A I}$ is standardized LAI; and $L A I_{\min / \max }$ is the minimum and maximum LAI value.

Then, the sediment load (SL) can be calculated by:

$$
S L=Q \times S S C .
$$

Considering data shortage in DRB, NSRC is developed based on time series of $M_{L A I}$ and streamflow to estimate sediment load changes from the changing streamflow and land cover in 
this study. To provide comprehensive assessment of this sediment model performance and indicate the accuracy of calculated curve, the same statistics and evaluation rules as in the BTOPMC model are used.

\section{Results and Discussion}

\subsection{Determination of Time Period with Human Distubances}

As mentioned before, we first determined the period affected the most strongly by human activities. According to the previous study [4], the Pettitt mutation test results indicated a change point in annual streamflow occurring in 1993 for both Lai Chau and Ta Bu hydrologic stations, which showed a significant upward trend in DRB. The period after 1993 was recognized as the period with the most serious human activities impact compared with the period before 1993. In addition, we also analyzed the change of NDVI from 1982 to 2006 and detected one obvious downward shift. Additionally, the average NDVI before and after 1993 also indicated that vegetation cover change affected by human activities was more serious after 1993 (Figure 4). Therefore, the period was divided into two parts: a pre-change period (1988-1993), representing streamflow under natural conditions, and a post-change period (1994-2004), representing streamflow under drastic human activities control. As a result, the period from 1994 to 2004 was selected as the target period to separate impacts of different environment changes on the streamflow and sediment load in this research.

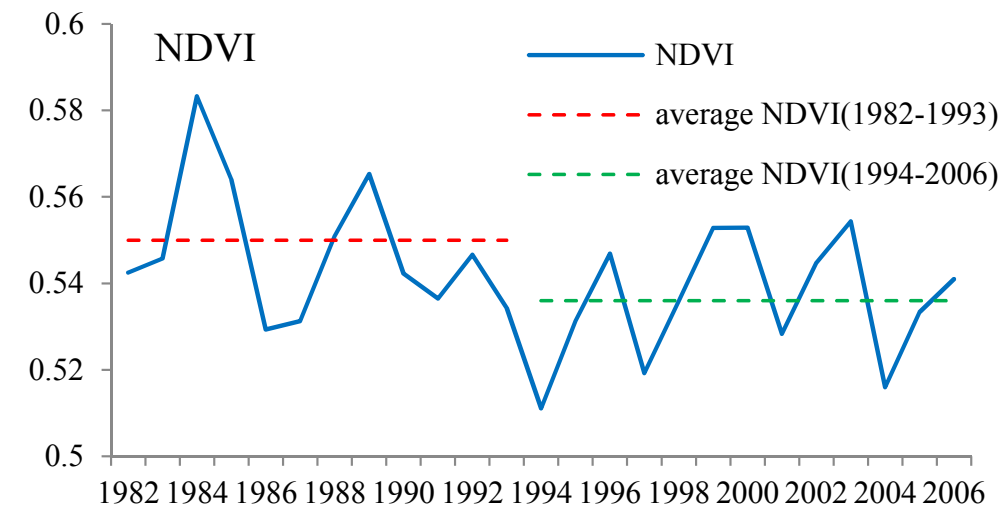

Figure 4. Change of annual maximum NDVI in the upstream of Laichau station (1982-2006).

\subsection{Hydrological Model and NSRC Model Simulation}

In this study, daily streamflow data for 1988-1993 are used for model calibration and validation of the BTOPMC hydrological model.The statistics for evaluation of the BTOPMC model give consistent results and good accuracy according to established criteria (Table 2).Direct comparison of the daily simulated to observed data of the streamflow in the pre-change period shows a reasonable match with observed data at the Lai Chau and the Ta Bu stations (Figure 5). Thus, the BTOPMC hydrological model could simulate streamflow in DRB well.

Table 2. Evaluation of model simulation during the pre-change period for the catchments controlled by Laichau and Tabu stations in the Da River Basin (DRB).

\begin{tabular}{lllll}
\hline & \multicolumn{2}{c}{ Laichau } & \multicolumn{2}{c}{ Tabu } \\
\cline { 2 - 5 } & Calibration & Validation & Calibration & Validation \\
\hline$R^{2}$ & 0.92 & 0.88 & 0.94 & 0.89 \\
NSE & 0.93 & 0.89 & 0.90 & 0.87 \\
MAE $(m m)$ & 3.76 & 4.49 & 2.96 & 3.71 \\
PBIAS $(\%)$ & 0.37 & 0.41 & 0.26 & 0.27 \\
\hline
\end{tabular}



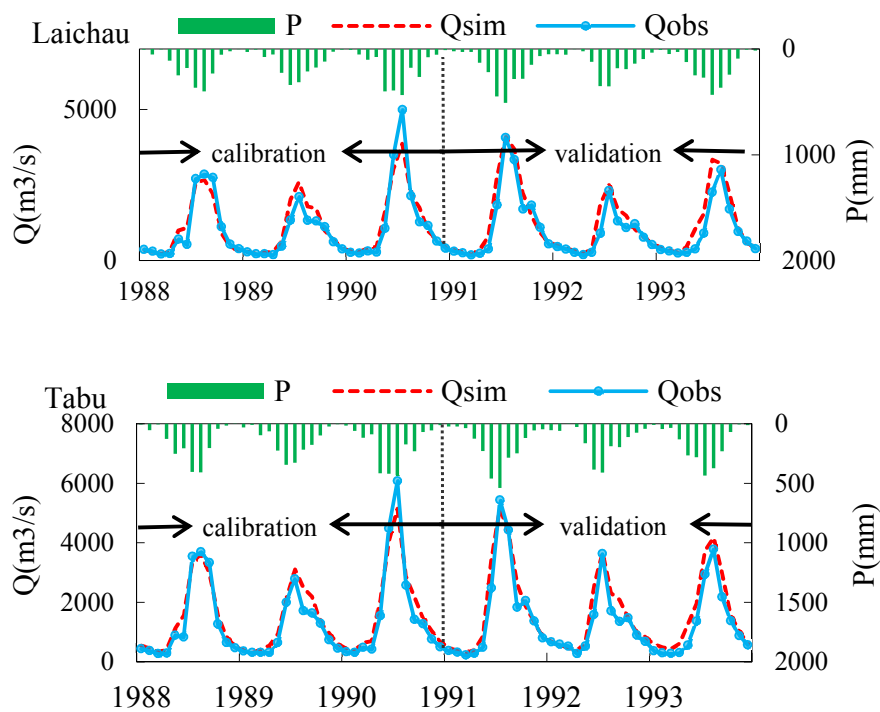

Figure 5. Comparison of observed and simulated monthly streamflow in the DRB.

NSRC model is used to calculate SSC for the period from 1988 to 1993, as the following equation:

$$
S S C=0.41\left(1-M_{L A I}{ }^{6.5}\right) Q^{1.5} .
$$

Results show well noted correlation between simulated and observed monthly SSC (Figure 6). The same three statistical criteria to evaluate new sediment rating curves indicate good agreement with established validation techniques. High NSE (0.86), low RSR and PBIAS (Table 3) suggest that NSRC can evaluate SSC accurately at the Lai Chau station and can be applied to well simulate SSC or sediment load in the DRB.
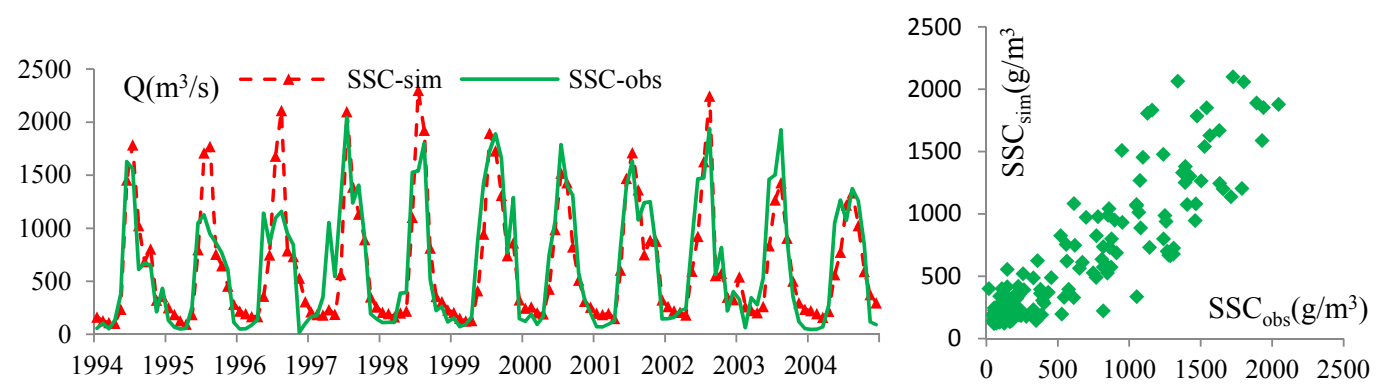

Figure 6. Comparison of observed and simulated monthly SSC at the Laichau station.

Table 3. Performance of new sediment rating curve for the Laichau station.

\begin{tabular}{cccc}
\hline Catchment & NSE & MAE $\left(\mathrm{g} / \mathrm{m}^{\mathbf{3}}\right)$ & PBIAS (\%) \\
\hline Laichau & 0.86 & 3.21 & 0.634 \\
\hline
\end{tabular}

\subsection{Modeled Actual and Potential LAI Analysis}

As mentioned above, the point-scale Biome-BGC model was used for simulating gridded basin to evaluate land cover change under climate change. Comparing simulated and observed monthly basin average LAI from 1982 to 1993, the simulated LAI showed a good match with the satellite observed values (Figure 7). In addition, the high $R^{2}$ value (0.772) also suggests that this ecological model is capable of simulating LAI reasonably well. Moreover, we compared simulated and satellite annual maximum LAI from 1982 to 2006 shown on Figure 8. It is obvious that the annual simulated LAI 
matches the observed values before 1994 well, and there is some partial difference in the post-change period. Then, grid maximum monthly and annual potential LAI from 1994 to 2004 were generated from the model to analyze the potential land cover conditions.

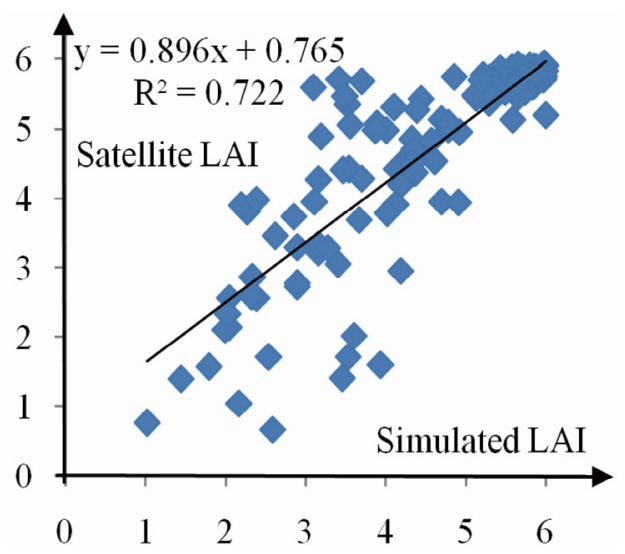

Figure 7. Scatterplot of satellite and simulated monthly basin average LAI.

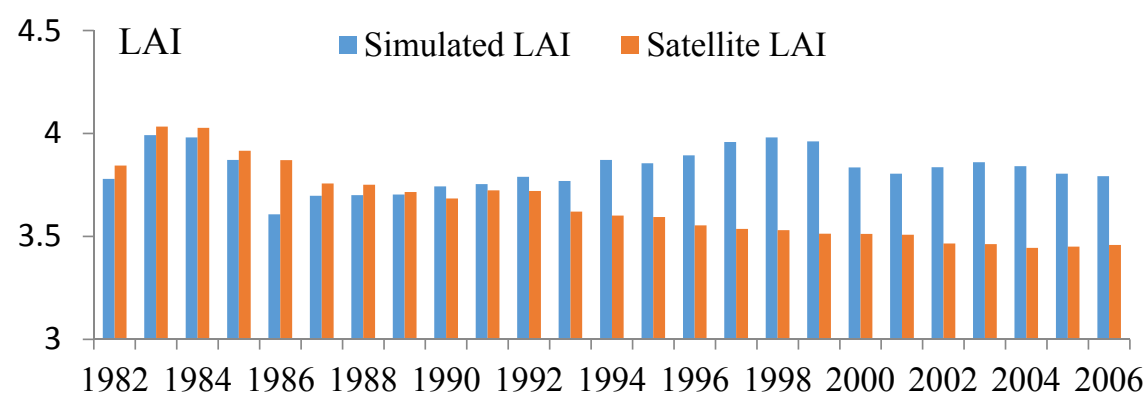

Figure 8. Comparison between simulated and satellite annual maximum LAI.

In order to quantify land cover change in detail, satellite observed LAI was used to reflect actual land cover change caused by combination of climate change and human activities, and simulated potential LAI by an ecological model representing climate-induced land cover change. The difference between the two was considered the true impacts from human-induced land cover change. Thus, the linear trend of annual LAI from GIMMS and potential LAI from the Biome-BGC model forced by real climate data alone were further calculated to identify these complex land cover changes (Figure 9), which expressed some inverse trend between actual LAI and potential LAI from 1982 to 2006. Almost all of the area in the basin showed a decreasing trend for the actual LAI whereas most grids had an increasing trend for potential LAI. On the other hand, the maximum decreasing trend of actual LAI is 0.12 , much higher than the increasing slope of 0.01 , and the maximum increasing trend of potential LAI is 0.13 , much higher than the decreasing slope of 0.05 . This unsymmetrical result also showed that human actives aversely changed the trend of land cover. To quantify this type of land cover change, LAI were then standardized according to the Equation (12). Results showed that the average standardized potential LAI $\left(M_{L A I p}\right)$ was larger than the standardized actual LAI $\left(M_{L A I C}\right)$ for almost all the months including the wet and dry season (Figure 10). As shown in Table 4, two statistics were used to evaluate changes of the land cover without the effect of human activities. The changes between $M_{L A I p}$ and $M_{L A I c}$ for the wet season, dry season, and annual average were different, which indicated that land cover changed severely and human activities affected it stronger in the dry season in the DRB. 


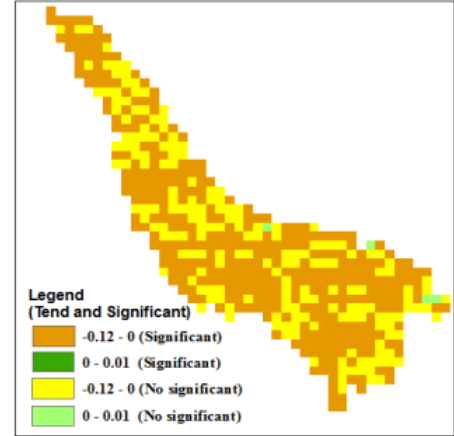

(a)

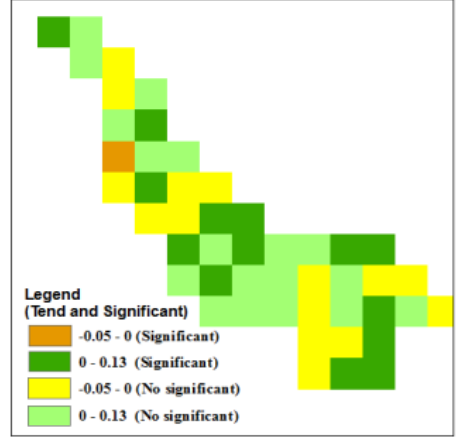

(b)

Figure 9. (a) Linear slope of annual maximum LAI from GIMMS; (b) Linear slope of annual maximum LAI from the Biome-BGC model (1982-2006) (Significant: passed significance level of 0.05).

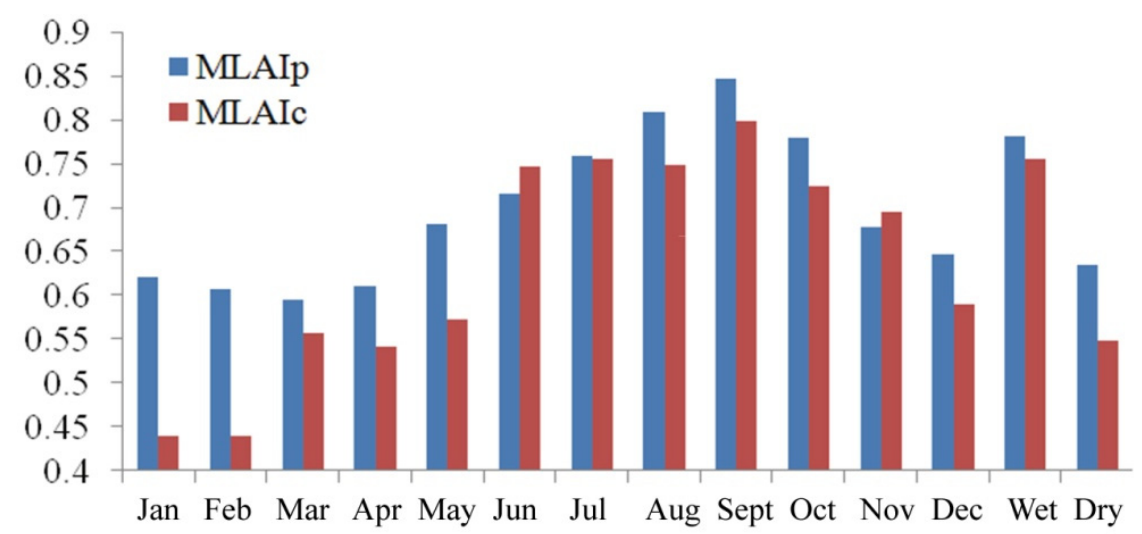

Figure 10. Comparison of average standardized potential LAI $\left(M_{L A I p}\right)$ and actual LAI $\left(M_{L A I c}\right)$ from 1994 to 2004.

Table 4. Statistic results of comparison between $M_{L A I p}$ and $M_{L A I c}$ from 1994 to 2004.

\begin{tabular}{cccc}
\hline & Wet Season & Dry Season & Annual Average \\
\hline$M_{L A I p}$ & 0.783 & 0.635 & 0.696 \\
$M_{L A I c}$ & 0.756 & 0.548 & 0.636 \\
$M A E$ & 0.027 & 0.087 & 0.06 \\
PBIAS $(\%)$ & 3.57 & 15.88 & 9.43 \\
\hline
\end{tabular}

\subsection{Effects of New Reclassified Environmental Changes on Streamflow and Sediment Load}

In this research, we reclassified all environmental changes related to river streamflow and sediment load as the following: climate change including meteorological changes (such as precipitation, temperature changes) and climate-induced land cover change; human activities including human-induced land cover change and other human activities. According to attribution analysis method, the total change of the streamflow $\left(\Delta Q^{\text {tot }}\right)$ was separated as $\Delta Q^{c l i}$ and $\Delta Q^{h u m}$ in different seasons, which was listed in Table 5 . Seasonal and annual changes show expected increase for both the Lai Chau and Ta Bu with different magnitudes. Results show that human activities account for $65 \%, 56.0 \%$ in the wet season and the dry season for the Lai Chau catchment, and $62.5 \%$ of the total streamflow change for the whole year, and $69.0 \%, 59.0 \%$ and $66.4 \%$ for the Ta Bu catchment respectively. Climate change contribution accounts for $35.0 \%$ of the wet season, $44 \%$ of the dry season, and $37.5 \%$ of the whole year at the Lai Chau and $31.0 \%$ of the wet season, $41.0 \%$ of the dry season, and $33.6 \%$ of the whole year at the Ta Bu catchments. Generally, an increase of annual and seasonal streamflow 
caused by artificial disturbances is larger than the increment caused by climate change in the DRB. The contribution ratio of human activities effect to streamflow changes is a little higher in the wet season at the Lai Chau and Ta Bu station.

Table 5. Effects of human activities and climate change on the annual streamflow (mm) across catchments controlled by hydrological stations in the DRB (subscript 1: 1988-1993; subscript 2: 1994-2004).

\begin{tabular}{|c|c|c|c|c|c|c|c|c|c|}
\hline \multirow{2}{*}{ Station } & \multirow{2}{*}{ Time Scale } & \multirow{2}{*}{$\bar{Q}_{1}^{\text {obs }}$} & \multirow{2}{*}{$\bar{Q}_{2}^{o b s}$} & \multirow{2}{*}{$\bar{Q}_{2}^{s i m_{c l i}}$} & \multirow{2}{*}{$\Delta Q^{t^{\circ} t}$} & \multirow{2}{*}{$\Delta Q^{c l i}$} & \multirow{2}{*}{$\Delta Q^{h u m}$} & \multirow{2}{*}{$\begin{array}{c}\text { Clim } \\
\% \\
\end{array}$} & \multirow{2}{*}{$\begin{array}{c}\text { Hum } \\
\%\end{array}$} \\
\hline & & & & & & & & & \\
\hline \multirow{3}{*}{ LC } & wet season & 1726.8 & 1982.9 & 1816.4 & 256.1 & 89.6 & 166.5 & 35.0 & 65.0 \\
\hline & dry season & 381.5 & 479.5 & 424.6 & 98.0 & 43.1 & 54.9 & 44.0 & 56.0 \\
\hline & annual & 1054.2 & 1231.1 & 1120.5 & 176.9 & 66.3 & 110.6 & 37.5 & 62.5 \\
\hline \multirow{3}{*}{$\mathrm{TB}$} & wet season & 2235.2 & 2784.9 & 2405.6 & 549.7 & 170.4 & 379.3 & 31.0 & 69.0 \\
\hline & dry season & 493.8 & 690.6 & 574.5 & 196.8 & 80.7 & 116.1 & 41.0 & 59.0 \\
\hline & annual & 1364.6 & 1738.0 & 1490.1 & 373.4 & 125.5 & 247.9 & 33.6 & 66.4 \\
\hline
\end{tabular}

(Wet season: May to October; dry season: November to April).

Table 6. Effects of human activities and climate change on the annual sediment load ( $10^{6}$ ton/year) of Lai Chau station (subscript 1: 1988-1993; subscript 2: 1994-2004).

\begin{tabular}{|c|c|c|c|c|c|c|c|c|c|}
\hline \multirow{2}{*}{ Station } & \multirow{2}{*}{ Time Scale } & \multirow{2}{*}{$\overline{S L}_{1}^{o b s}$} & \multirow{2}{*}{$\overline{S L}_{2}^{\text {obs }}$} & \multirow{2}{*}{$\overline{S L Q}_{2}^{s i m_{c l i}}$} & \multirow{2}{*}{$\Delta S L^{\iota^{\circ} t}$} & \multirow{2}{*}{$\Delta S L^{c l i}$} & \multirow{2}{*}{$\Delta S L^{h u m}$} & Clim & Hum \\
\hline & & & & & & & & $\%$ & $\%$ \\
\hline \multirow{3}{*}{$\mathrm{LC}$} & Wet season & 65.3 & 79.8 & 69.2 & 14.5 & 3.9 & 10.6 & 26.9 & 73.1 \\
\hline & Dry season & 4.8 & 5.9 & 5.3 & 1.1 & 0.4 & 0.7 & 40.0 & 60.0 \\
\hline & Annual & 35.1 & 42.9 & 37.4 & 7.8 & 2.3 & 5.5 & 29.5 & 70.5 \\
\hline
\end{tabular}

The contribution of climate change and artificial disturbance in sediment load changes is calculated in Table 6. Similar with streamflow, sediment load also shows an obvious increase in the post-change period for the whole year, wet season and dry season. The results show that the proportions of artificial disturbance effect to the total change of sediment load accounts for $70.5 \%$, $73.1 \%$ and $60.0 \%$ in the whole year, in the wet season and the dry season, and $29.5 \%, 26.9 \%$ and $40.0 \%$ for climate change at the Lai Chau station.

\subsection{Discussion}

\subsubsection{Changes of Land Cover Changes and Their Impacts}

Generally, human activities and climate variability are the main factors affecting streamflow or sediment load. Land cover changes' effects are more challenging to diagnose and quantify since we reclassified it in two parts in this study: climate-induced and human-induced land cover change. Previous research confirmed climate-induced land cover change as human activities. On the contrary, we considered its effects as a part of climate change impacts. As a result, human-induced land cover changes were the main human activities in our research period since no other drastic human activities were found in the DRB [4,16,17]. Although the spatial distribution of land cover is dominantly controlled by climate on a global scale [41-43], recent studies concluded that regional land cover change has been mainly changed by humans [44-46]. Our results support that human actions are the main factor altering the land cover changes in the DRB through analyzing differences between satellite LAI and simulated LAI from Biome-BGC model. Deforestation was confirmed as the main land cover change in the DRB $[16,17,19]$. On the other hand, potential LAI without impacts of human activities indicated that forests would have flourished more due to the increased rainfall $[42,43]$. From the view of different seasons, changes of the human-induced land cover in the dry season are strongest because it is the best season of logging in the DRB. Climate-induced land cover changes are hardly 
to be controlled in a short time period, however, it is easy to carry out countermeasures for slowing down streamflow and sediment load changes by reversing human-induced land cover changes.

Deforestation was demonstrated to increase river streamflow and sediment load as the main human-induced land cover change $[8,15,17,22]$. Similar with this study, Wang et al. [4] concluded that human activities (land cover changes) are the main reason to affect changes in streamflow in the DRB. Nevertheless, a higher contribution of human activity impacts on streamflow and sediment load (Table 7) was calculated in our study because climate-induced land cover change played a negative role (Table 8) on the increase of streamflow and sediment load. This higher rate contribution indicated climate-induced land cover change could weaken the increase of streamflow and sediment load in the DRB. Although human-induced land cover changed more in the dry season than in the wet season, the absolute change of streamflow and sediment load affected by human-induced land cover changes was higher in the wet season (Tables 4-6). This is due to its rainy weather, which implied that a precondition of land cover change impacts on streamflow and sediment load was the occurrence of enough precipitation. Comparing results of streamflow and sediment load changes separation, we can find that human-induced land cover change effect on sediment load is stronger than the streamflow in the DRB, which argued that changes of land cover may be more sensitive to sediment load [8]. Sediment load of the Lai Chau station draining 2/3 of the area of the DRB was considered as the main sediment flow into the Hoa Binh reservoir downstream. Therefore, due to the increased sediment flow into the reservoir and the reservoir siltation itself, the useful lifetime of the Hoa Binh reservoir would be shortened quickly, which would cause the risk of flood risk to increase and hydropower generation reduction in the Red River area. Thus, countermeasures to protect land cover should be carried out to extend useful lifetime of the reservoir.

Table 7. Comparison with previous research.

\begin{tabular}{|c|c|c|c|}
\hline \multirow{2}{*}{ Station } & \multirow{2}{*}{ Results Source } & Clim & Hum \\
\hline & & $\%$ & $\%$ \\
\hline \multirow{2}{*}{ LC(Streamflow) } & $\mathrm{A}$ & 37.5 & 62.5 \\
\hline & B & 46.0 & 54.0 \\
\hline \multirow{2}{*}{ TB(Streamflow) } & A & 33.6 & 66.4 \\
\hline & B & 40.0 & 60.0 \\
\hline \multirow{2}{*}{ LC(Sediment load) } & $\mathrm{A}$ & 29.5 & 70.5 \\
\hline & B & 36.0 & 64.0 \\
\hline
\end{tabular}

Note: A: Our results; B: Results from Reference [4].

Table 8. Environmental changes and their impacts.

\begin{tabular}{ccc}
\hline Type & Behaviour & $\begin{array}{c}\text { Increase of Streamflow } \\
\text { and Sediment Load }\end{array}$ \\
\hline $\begin{array}{c}\text { Climate change } \\
\text { Climate-Induced land cover change }\end{array}$ & $\begin{array}{c}\text { Increasing rainfall } \\
\text { More frequent forest } \\
\text { Human-induced land cover change }\end{array}$ & $\begin{array}{c}\text { Positive } \\
\text { Forest degradation }\end{array}$ \\
\hline
\end{tabular}

\subsubsection{Uncertainties Analysis}

Despite the fact that well validated models gave us much information for ungauged watersheds, uncertainties still existed in our study due to many factors: potential errors in input datasets, model parameters and simplification of ecological or hydrological process [47-49]. For example, Li et al. found that high uncertainty existed in various model parameters and different scale model simulations [47]. Additionally, although atmospheric $\mathrm{CO}_{2}$ concentration was considered to simulate potential LAI in ecological models, it was not included in our hydrological and sediment simulation models [30,31,40]. 
Other human disturbances such as agricultural irrigation water use, urban water consumption and especially dam construction have also likely affected streamflow and sediment load [23,50].

All factors mentioned above may have led to unrealistic simulation results in our study. To effectively reduce uncertainty in model simulations, more field observations should be done $[47,48]$. It was also demonstrated that ensemble techniques are helpful for uncertainty analysis. Therefore, more field observations should be carried out and an integrated approach considering other influencing factors should be developed in the future.

\section{Conclusions}

The interaction and feedback among streamflow, sediment load and land cover is complex. Degradation of forests in DRB is caused by humans. As the main human-induced land cover changes, especially in the dry season, deforestation could result in a bigger increase of water yield and sediment load than climate change. Climate change would have the potential to increase vegetation greenness, which could weaken the increase of streamflow and sediment load in the Da River Basin. Deforestation impacts on water yield and sediment load are more pronounced in the wet season, with a stronger influence on the sediment load due to its being doubly affected by changes of streamflow and land cover.

Overall, the research provided a framework for attribution analyses of multiple environmental changes on streamflow and sediment load in a mountainous basin. Since climate-induced land cover changes may not stop in a short time period in this study region, impact analysis on the individual contributions of human-induced land cover changes could be valuable for the local government in decision-making. This study also could provide guidance for future similar studies in other basins that are rarely gauged. Such information could be critically important in directing efforts in managing land use, improving agricultural practices, flood control and soil conservation in the rapidly changed environments in Vietnam.

Acknowledgments: This research was supported by the National Natural Science Foundation of China (Grant No. 41501029, No. 91425301 and No. 41202174), the Natural Science Foundation of Jiangsu Province (Grant No. BK20150922, BK20151525), and the Startup Foundation for Introducing Talent of Nanjing University of Information Science \& Technology (NUIST). The authors are also thankful to the Vietnam Academy of Science and Technology and China Meteorological Data Sharing Service Center for providing the hydro-meteorological data.

Author Contributions: This manuscript was primarily designed and written by Jie Wang; Shaowei Ning contributed to its model simulation and calculation. Guiping Yin and Lijuan Guo supported the dataset and data analysis; Hiroshi Ishidaira supervised the research and critically reviewed the draft; Timur Khujanazarov polished the English writing of this draft.

Conflicts of Interest: The authors declare no conflict of interest.

\section{References}

1. Schulze, R.E. Modelling hydrological responses to land use and climate change: A southern African perspective. Ambio 2000, 29, 12-22. [CrossRef]

2. Sun, S.L.; Chen, H.S.; Ju, W.M.; Hua, W.J.; Yu, M.; Yin, Y.X. On the attribution of changing hydrological cycle in Poyang Lake Basin, China. J. Hydrol. 2014, 514, 214-225. [CrossRef]

3. Le, T.P.Q.; Garnier, J.; Gilles, B.; Sylvain, T.; van Minh, C. The changing flow regime and sediment load of the Red River, Viet Nam. J. Hydrol. 2007, 334, 199-214. [CrossRef]

4. Wang, J.; Ishidaira, H. Effects of climate change and human activities on streamflow and sediment flow into the Hoa Binh reservoir. J. Jpn. Soc. Civil Eng. Ser.B1 (Hydraul. Eng.) 2012, 68, I91-I96. [CrossRef]

5. Wardrop, D.H.; Brooks, R.P. The Occurrence and impact of sedimentation in central Pennsylvania wetlands. Environ. Monit. Assess. 1998, 51, 119-130. [CrossRef]

6. Garcia-Ruiz, J.M.; Lana-Renault, N. Hydrological and erosive consequences of farmland abandonment in Europe, with special reference to the Mediterranean region-A review. Agric. Ecosyst. Environ. 2011, 140, 317-338. [CrossRef] 
7. José Marques, M.; Bienes, R.; Jiménez, L.; Pérez-Rodríguez, R. Effect of vegetation cover on runoff and soil erosion under light intensity events. Rainfall simulation over USLE. Sci. Total Environ. 2007, 378, 161-165. [CrossRef] [PubMed]

8. Tang, L.H.; Yang, D.W.; Hu, H.P.; Gao, B. Detecting the effect of land-use change on streamflow, sediment and nutrient losses by distributed hydrological simulation. J. Hydrol. 2011, 409, 172-182. [CrossRef]

9. Nguyen, N.L.; Vo, D.H. Initiate Results of Research on Impacts of Several Main Vegetative Types on Water Sources and the Principles to Establish Forests for Water Protection; Agricultural Publishing House: Hochiminh, Vietnam, 1997; p. 156.

10. Brown, A.E.; Zhang, L.; McMahon, T.A.; Western, A.W.; Vertessy, R.A. A review of paired catchment studies for determining changes in water yield resulting from alterations in vegetation. J. Hydrol. 2005, 310, $28-61$. [CrossRef]

11. Zhao, F.F.; Xu, Z.X.; Zhang, L.; Zuo, D.P. Streamflow response to climate variability and human activities in the upper catchment of the Yellow River Basin. Sci. China Ser. E: Technol. Sci. 2009, 52, 3249-3256. [CrossRef]

12. Stephen, J.W.; Thomas, W.C.; William, F.W.; Kelley, A.C.M. A multiscale analysis of LULC and NDVI variation in Nang Rong district, northeast Thailand. Agric. Ecosyst. Environ. 2001, 85, 47-64.

13. Tucker, C.J.; Pinzon, J.E.; Brown, M.E.; Slavback, D.; Park, E.W.; Mahoney, R.; Vermote, E.; Saleous, N.E. An extended AVHRR 8-km NDVI dataset compatible with MODIS and SPOT vegetation NDVI data. Int. J. Remote Sens. 2005, 26, 4485-4498. [CrossRef]

14. MOSTE. Vietnamese General Statistics Officer, Ministry of Science, Technology and Environment of Vietnam, General Statistics Editor; MOSTE: Hanoi, Vietnam, 1997.

15. Fullen, M.A.; Mitchell, D.J.; Barton, A.P.; Hocking, T.J.; Liu, L.G.; Wu, B.Z.; Zheng, Y.; Xia, Z.Y. Soil erosion and Conservation in the Headwaters of the Yangtze River, Yunnan Province, China. In Headwaters: Water Resources and Soil Conservation, Proceedings of the Headwater '98, the Fourth International Conference on Headwater Control, Merano, Italy, 1998; Haigh, M.J., Krecek, J., Rajwar, S., Kilmartin, M.P., Eds.; pp. $299-306$.

16. United Nations Environment Programme (UNEP). China Conservation Strategy; UNEP \& China Environmental Science Press: Beijing, China, 1990.

17. Ye, C.Q.; Gan, S.; Wang, W.L.; Deng, Q.Y.; Chen, W.H.; Li, Y.G. Analysis on the runoff distribution and the variability in the downstream of Honghe River. Resour. Environ. 2008, 17, 886-891.

18. World Bank. Vietnam Water Resources Sector Review. Selected Working Papers of the World Bank, ADB, FAO/UNP and NGO Water Resources Sectoral Group; World Bank: Hanoi, Vietnam, 1996; p. 340.

19. Forest Science Institute of Vietnam (FSIV). Vietnam Forestry Outlook Study, Asia-Pacific Forestry Sector Outlook Study II. Working Paper Series; Forest Science Institute of Vietnam (FSIV): Hoanoi, Vietnam, 2009.

20. He, D.M.; Wu, S.H.; Peng, H.; Yang, Z.F.; Ou, X.K.; Cui, B.S. A study of ecosystem changes in Longitudinal Range-Gorge Region and transboundary eco-security in southwest China. Adv. Earth Sci. 2005, 20, 338-344.

21. Tuan, V.V. Evaluation of the impact of deforestation to inflow regime of the Hoa Binh Reservoir in Vietnam. In Proceedings of the Yokohama Symposium, Hydrology of Warm Humid Regions, Yokohama, Japan, 13-15 July 1993; pp. 135-138.

22. Ren, J.; Hen, D.M.; Fu, K.D.; Li, Y.G. Sediment change under climate changes and human activities in the Yuanjiang-Red River Basin. Chin. Sci. Bull. 2007, 52, 164-171.

23. Dang, T.H.; Coynel, A.; Orange, D.; Blanc, G.; Etcheber, H.; Le, L.A. Long-term monitoring (1960-2008) of the river-sediment transport in the Red River Watershed (Vietnam): Temporal variability and dam-reservoir impact. Sci. Total Environ. 2010, 408, 4654-4664. [CrossRef] [PubMed]

24. Yatagai, A.; Kamiguchi, K.; Arakawa, O.; Hamada, A.; Yasutomi, N.; Kitoh, A. APHRODITE: Constructing a Long-term Daily Gridded Precipitation Dataset for Asia based on a Dense Network of Rain Gauges. Bull. Am. Meteorol. Soc. 2012, 93, 1401-1415. [CrossRef]

25. Harris, I.; Jones, P.D.; Osborn, T.J.; Lister, D.H. Updated high-resolution grids of monthly climatic observations-The CRU TS3.10 Dataset. Int. J. Climatol. 2013, 34, 623-642. [CrossRef]

26. Bliss, N.B.; Olsen, L.M. Development of a 30-arc-second digital elevation model of South America. In Proceedings of the Pecora Thirteen, Human Interactions with the Environment-Perspectives from Space, Sioux Falls, SD, USA, 20-22 August 1996.

27. Global 30 Arc-Second Elevation (GTOPO30). Available online: https://lta.cr.usgs.gov/GTOPO30 (accessed on 27 Janunary 2016). 
28. DIGITAL SOIL MAP OF THE WORLD. Available online: http://www.fao.org/geonetwork/srv/en/metadata. show?id=14116 (accessed on 27 Janunary 2016).

29. Zhu, Z.C.; Bi, J.; Pan, Y.Z.; Ganguly, S.; Anav, A.; Xu, L.; Samanta, A.; Piao, S.L.; Nemani, R.R.; Myneni, R.B. Global Data Sets of Vegetation Leaf Area Index (LAI) $3 \mathrm{~g}$ and Fraction of Photosynthetically Active Radiation (FPAR) $3 \mathrm{~g}$ Derived from Global Inventory Modeling and Mapping Studies (GIMMS) Normalized Difference Vegetation Index (NDVI3g) for the Period 1981 to 2011. Remote Sens. 2013, 5, 927-948.

30. Pettitt, A. A nonparametric approach to the change-point problem. Appl. Stat. 1979, 28, 126-135. [CrossRef]

31. Takeuchi, K.; Ao, T.Q.; Ishidaira, H. Introduction of blockwise use of TOPMODEL and Muskingum-Cunge method for the hydro-environmental simulation of a large ungauged catchment. Hydrolog. Sci. J. 1999, 44, 633-646. [CrossRef]

32. Ishidaira, H.; Takeuchi, K.; Ao, T. Hydrological simulation of large river basins in Southeast Asia. In Proceedings of the Fresh Perspectives on Hydrology and Water Resources in Southeast Asia and the Pacific, ChristChurch, New Zealand, 21-24 November 2000; pp. 53-54.

33. Beven, K. Linking parameters across scales-sub grid parameterizations and scale-dependent hydrological models. Hydrol. Process. 1995, 9, 507-525. [CrossRef]

34. Shrestha, S.; Bastola, S.; Babel, M.S.; Dulal, K.N.; Magome, J.; Hapuarachchi, H.A.P.; Kazama, F.; Ishidaira, H.; Takeuchi, K. The assessment of spatial and temporal transferability of a physically based distributed hydrological model parameters in different physiographic regions of Nepal. J. Hydrol. 2007, 347, 153-172. [CrossRef]

35. Moriasi, D.N.; Arnold, J.G.; van Liew, M.W.; Bingner, R.L.; Harmel, R.D.; Veith, T.L. Model evaluation guidelines for systematic quantification of accuracy in watershed simulations. Trans. ASABE 2007, 50, 885-900. [CrossRef]

36. Running, S.W.; Gower, S.T. FOREST-BGC, A general model of forest ecosystem processes for regional applications. Tree Physiol. 1991, 9, 147-160. [CrossRef] [PubMed]

37. Thornton, P.E.; Hasenauer, H.; White, M.A. Simultaneous estimation of daily solar radiation and humidity from observed temperature and precipitation: An application over complex terrain in Austria. Agric. For. Meteorol. 2000, 104, 255-271. [CrossRef]

38. Ichii, K.; Hashimoto, H.; Nemani, R.; White, M. Modeling the interannual variability and trends in gross and net primary productivity of tropical forests from 1982 to 1999. Glob. Planet. Chang. 2005, 48, 274-286. [CrossRef]

39. Asselman, N.E.M. Fitting and interpretation of sediment rating curves. J. Hydrol. 2000, 234, $228-248$. [CrossRef]

40. Howe, A.; Rodriguez, J.; MacFarlane, G. Vegetation Sediment Flow Interactions in Estuarine Wetlands. In Proceedings of the MODSIM 2005 International Congress on Modelling and Simulation Zerger, Modelling and Simulation Society of Australia and New Zealand, Melbourne, Australia, 12-15 December 2005; pp. 332-338.

41. Wang, J.; Ishidaira, H.; Sun, W.C.; Ning, S.W. Development and Interpretation of New Sediment Rating Curve Considering the Effect of Vegetation Cover for Asian Basins. Sci. World J. 2013, 2013, 154375. [CrossRef] [PubMed]

42. Gallimore, R.; Jacob, R.; Kutzbach, J. Coupled atmosphere-ocean-vegetation simulations for modern and mid Holocene climates: Role of extratropical vegetation cover feedbacks. Clim. Dyn. 2005, 25, 755-776. [CrossRef]

43. Liu, Z.; Notaro, M.; Kutzbach, J.; Liu, N. Assessing global vegetation-climate feedbacks from observations. J. Clim. 2006, 19, 787-814. [CrossRef]

44. Smith, V.B.; David, C.H.; Cardenas, M.B.; Yang, Z.L. Climate, river network, and vegetation cover relationships across a climate gradient and their potential for predicting effects of decadal-scale climate change. J. Hydrol. 2013, 488, 101-109. [CrossRef]

45. Tilman, D.; Lehman, C. Human-caused environmental change: Impacts on plant diversity and evolution. Proc. Natl. Acad. Sci. USA 2001, 98, 5433-5440. [CrossRef] [PubMed]

46. Chaudhry, G.P.; Saroha, B.S.; Yadav, M. Human Induced Land Use/Land Cover Changes in Northern Part of Gurgaon District, Haryana, India: Natural Resources Census Concept. J. Hum. Ecol. 2008, 23, 243-252.

47. Taub, D. Effects of Rising Atmospheric Concentrations of Carbon Dioxide on Plants. Nat. Educ. Knowl. 2010, 3,21 . 
48. Li, N.; McLaughlin, D.; Kinzelbach, W.; Li, W.; Dong, G. Using an ensemble smoother to evaluate parameter uncertainty of an integrated hydrological model of Yanqi basin. J. Hydrol. 2015, 529, 146-158. Available online: http://dx.doi.org/10.1016/j.jhydrol.2015.07.024. [CrossRef]

49. Arnold, S.; Attinger, S.; Frank, K.; Hildebrandt, A. Uncertainty in parameterisation and model structure affect simulation results in coupled ecohydrological models. Hydrol. Earth Syst. Sci. 2009, 13, 1789-1807.

50. Christiaens, K.; Feyen, J. Use of sensitivity and uncertainty measures in distributed hydrological modeling with an application to the MIKE SHE model. Water Resour. Res. 2002, 38. [CrossRef]

51. Zhao, G.; Tian, P.; Mu, X.; Jiao, J.; Wang, F.; Gao, P. Quantifying the impact of climate variability and human activities on streamflow in the middle reaches of the Yellow River basin, China. J. Hydrol. 2014, 519, 387-398. [CrossRef]

(C) 2016 by the authors; licensee MDPI, Basel, Switzerland. This article is an open access article distributed under the terms and conditions of the Creative Commons by Attribution (CC-BY) license (http://creativecommons.org/licenses/by/4.0/). 